\title{
DEVELOPMENT OF APPLE TISSUE AND ACID TREATED MULTI-WALLED CARBON NANOTUBE BASED AMPEROMETRIC BIOSENSOR FOR PHENOL DETECTION
}

Tuğba ÖREN VAROL*, Chemistry Department, Faculty of Science, Muğla Sıtkı Koçman University, 48000, Kötekli/Muğla, Turkey,

tugbaoren@mu.edu.tr

(iD) https://orcid.org/ 0000-0003-3680-5743)

Received: 07.01.2021, Accepted: 19.04.2021

Research Article

*Corresponding author

DOI: $10.22531 /$ muglajsci.855685

\section{Abstract}

The fabrication of acid functionalized multi-walled carbon nanotube (fMWCNT) combined apple tissue based amperometric biosensor through a cross-linking agent-free approach has been presented for the phenol detection in this study. Apple tissue entrapped in fMWCNT-glassy carbon paste composite was employed as the natural polyphenol oxidase source for the enzymatic oxidation of phenol and the consumption of the dissolved oxygen was monitored via chronoamperometry as the biosensor response. The effect of experimental parameters (e.g. working potential, pH and tissue amount) were examined to obtain the optimum measurement conditions. Under optimized conditions, amperometric responses linearly increased in the range of 10-200 $\mu \mathrm{M}$ phenol and limit of detection was calculated as 3.26 $\mu M(n=3)$. Apple tissue based biosensor was utilized for the phenol detection in tap water samples by serving satisfying recovery values.

Keywords: Apple tissue, polyphenol oxidase, phenol, amperometric biosensor, multi-walled carbon nanotube

\section{FENOL TAYINI İÇIN ELMA DOKUSU VE ASITLE MUAMELE EDILMIŞ ÇOK DUVARLI KARBON NANOTÜP TEMELLI AMPEROMETRIK BIYOSENSÖR GELIŞTIRILMESI}

\section{Özet}

Bu çalışmada, fenol tayini için asit fonksiyonelleştirilmiş çok duvarlı karbon nanotüp (f-ÇDKNT) ile kombinlenmiş elma dokusu temelli amperometrik biyosensörün çapraz bağlayıcı kullanılmayan bir yaklaşımla üretimi sunulmuştur. $f$ ÇDKNT-camsı karbon pasta kompoziti içinde hapsedilmiş elma dokusu doğal polifenol oksidaz kaynağı olarak fenolün enzimatik yükseltgenmesi için kullanılmış ve çözünmüş oksijenin tüketimi biyosensör yanıtı olarak kronoamperometri ile izlenmiştir. Deneysel parametrelerin (çalışma potansiyeli, pH ve doku miktarı) etkileri optimum ölçüm koşullarının elde edilmesi için incelenmiştir. Optimum koşullarda, amperometrik yanıtlar 10-200 $\mu \mathrm{M}$ fenol aralı̆̆ında doğrusal olarak artmış ve gözlenebilme sınırı $3.26 \mu \mathrm{M}$ olarak hesaplanmıştır ( $n=3)$. Elma dokusu temelli biyosensör, musluk suyu örneklerindeki fenolün tatmin edici geri kazanım değerleriyle tayini için kullanılmıştır.

Anahtar Kelimeler: Elma dokusu, polifenol oksidaz, fenol, amperometrik biyosensör, çok duvarlı karbon nanotüp

Cite

Varol, T. Ö., (2021). “Development of Apple Tissue and Acid Treated Multi-Walled Carbon Nanotube Based Amperometric Biosensor for Phenol Detection", Mugla Journal of Science and Technology, 7(1), 100-105.

\section{Introduction}

Phenol and its derivatives have a widespread use in industry for the production of detergents, plastics, pesticides and pharmaceuticals. Besides, these compounds have been also utilized as precursors in crude oil refining, paper bleaching and coal mining. As a result of their conventional use, industrial wastewater streams and soil have been increasingly contaminated with phenolic compounds day by day. Therefore, phenolic compounds are classified as major toxic pollutants by United States Environmental Protection
Agency as well as European Commission. Apart from the environmental danger, carcinogenic and mutagenic effects of phenol and phenol derived compounds have posed a potential risk to human health [1-5]. Thus, monitoring of phenol and phenolic compounds level in environmental and biological samples requires accurate, sensitive and practical analytical methods. Within this purpose, spectroscopic and chromatographic methods have been accepted as standard methods for the analysis of phenolic compounds. However, these methods suffer from the need of overpriced equipment, tedious sample 
preparation procedures and well-trained personnel. Fabrication of efficient electrochemical biosensors have presented a new route for the practical detection of phenolic compounds with improved sensitivity and accuracy in recent years [6-9]. Most of the fabricated biosensors are based on enzymatic principle and polyphenol oxidase (PPO), laccase and peroxidase have been widely utilized as the biorecognition element within this scope $[7,10,11]$. As an alternative to the requirement of extremely pure enzymes with retained maximum enzymatic activity on the immobilized surface, plant tissues have come to prominent by serving preserved enzymatic activity due to the existence of enzymes in their native microenvironment $[7,12]$. Crude plant tissues and tissue homogenates of banana, mushroom, apple, pear, coconut, potato and eggplant have been successfully used for the determination of phenolic compounds such as phenol, catechol, bisphenol-A, dopamine, hydroquinone, salicylic acid and L-dopa [12-18].

Among the mentioned enzymes, PPO possesses at least one copper centered active site which is coordinated with histidine, methionine and cysteine. The activity of PPO is related with the binding and cleavage of oxygen in the metallic center leading to oxidation of the substrate (analyte) through monophenolase activity or hydroxylation of monophenols to o-diphenols (diphenolase activity) with subsequent oxidation to quinones. PPO can catalyze the oxidation of several phenolic compounds, therefore, it can be used for the fabrication of biosensors to detect total phenolic content by offering robust and stable structure [7, 14, 19, 20]. Hence, the fabrication of acid treated multi-walled carbon nanotube (fMWCNT) and apple tissue based biosensor has been presented in this study and phenol was chosen as the model substrate considering the majority of PPO containing plant tissue based biosensors were fabricated for catechol and L-dopa detection [14]. A cross-linking agent-free strategy was followed in the biosensor construction, so that a biocomposite of apple tissue, glassy carbon powder, fMWCNT and mineral oil binder was prepared in a similar manner with previous works [21-23]. Analytical characteristics of the fabricated biosensor were examined after the optimization of experimental parameters and the apple tissue based biosensor was practically tested for the detection of phenol in tap water samples.

\section{Experimental}

\subsection{Reagents and chemicals}

Glassy carbon (Aldrich, spherical powder with 2-12 $\mu \mathrm{m}$ particle size, $99.95 \%$ trace metals basis), MWCNT (Aldrich, 110-170 nm diameter, 5-9 $\mu \mathrm{m}$ length, 90+\%) and mineral oil (Sigma-Aldrich) were purchased for the biosensor fabrication. Red apples (Malus domestica) were supplied from a local market as the natural PPO source and kept at $4^{\circ} \mathrm{C}$ until use. Sulfuric acid $\left(\mathrm{H}_{2} \mathrm{SO}_{4}\right)$ and nitric acid $\left(\mathrm{HNO}_{3}\right)$ from Merck were used for the acid treatment of MWCNT. Phenol (Sigma-Aldrich, 99.0\%) was used to prepare standard solutions each day prior to measurements. Phosphate buffers (PB) with varying $\mathrm{pH}$ from 6.0 to 8.0 were prepared with required amounts of $0.1 \mathrm{M}$ solutions of $\mathrm{KH}_{2} \mathrm{PO}_{4}$ (Merck, 99.5\%) and $\mathrm{Na}_{2} \mathrm{HPO}_{4}$ (Sigma-Aldrich, 98.0-100.5\%). Uric acid, cysteine, ascorbic acid (Sigma) and salicylic acid (Kimetsan) were of analytical grade and used in the interference study. All solutions were prepared with ultrapure water.

\subsection{Apparatus}

Chronoamperometric measurements were performed at $25^{\circ} \mathrm{C}$ by using an Autolab PGSTAT 101 potentiostat/galvanostat with Nova 1.10 software. $\mathrm{Ag} / \mathrm{AgCl}(3 \mathrm{M} \mathrm{KCl}$ ) and $\mathrm{Pt}$ wire were utilized as reference and counter electrodes to measure the response of apple tissue based biosensor by serving a conventional three electrode configuration.

\subsection{Preparation of apple tissue based biosensor}

Apple tissue based biosensor (Apple tissue-fMWCNTGCPE) was prepared through homogeneous mixture of apple puree, fMWCNT, glassy carbon spherical powder and mineral oil at proper amounts. Initially, MWCNT was treated with $\mathrm{H}_{2} \mathrm{SO}_{4}$ and $\mathrm{HNO}_{3}$ mixture (3:1 by volume) to form oxygen containing functional groups in MWCNT structure based on a previously reported study $[24,25]$. Apple tissues to be used as the natural PPO source were obtained by grating apples to obtain an apple puree. Apple puree was stored at $4^{\circ} \mathrm{C}$ overnight for the enzymatic oxidation of phenolic compounds present in apple which is characterized by browning $[26,27]$. After the preparation of fMWCNT and apple tissues, glassy carbon spherical powder, fMWCNT, apple tissue and mineral oil were mixed to obtain a homogeneous paste in the mass ratio of $66: 4: 10: 20$. The obtained paste was carefully placed into the electrode cavity and biosensor surface was smoothened (Scheme 1). Fabricated biosensors were kept at $4^{\circ} \mathrm{C}$ under humidity when not in use as stated in a previously reported study [12].

\subsection{Electrochemical measurements}

Apple tissue-fMWCNT-GCPE, $\mathrm{Ag} / \mathrm{AgCl}$ reference electrode and Pt counter electrode were placed into the electrochemical cell containing required volume of $\mathrm{PB}$ solution ( $\mathrm{pH}$ 6.5). PB solution was mixed via a magnetic bar at approximately $300 \mathrm{rpm}$ and a constant potential of $-0.7 \mathrm{~V}$ was applied to monitor the reduction of oxygen as 


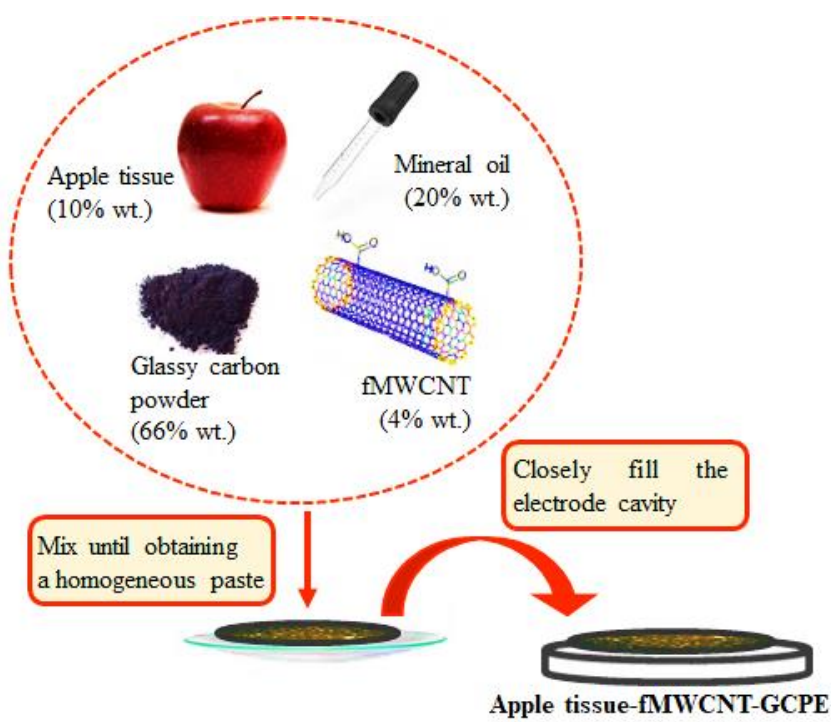

Scheme 1. Preparation of the apple tissue based biosensor (Apple tissue-fMWCNT-GCPE).

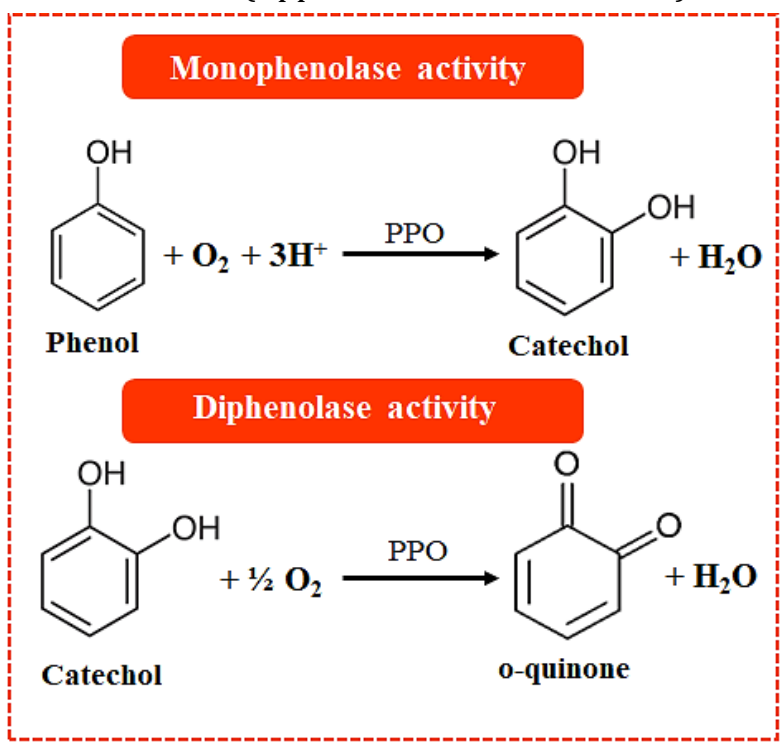

Scheme 2. PPO activity for the phenol oxidation.

a result of the enzymatic oxidation of phenol (Scheme 2) [14]. The transient current was reached to a steady state and phenol was carefully injected at $200 \mathrm{~s}$. At this point, current began to decrease in relation with the consumption of oxygen to produce water and then reached a steady state again. The current difference was evaluated as the biosensor response according to the reactions presented in Scheme 2.

\section{Results and Discussion}

\subsection{Optimization of the experimental parameters}

The catalytic effect of nanomaterials on the electrochemical signal improvement is a well-known phenomenon as demonstrated in previous studies [7, 21, 28]. fMWCNT amount used in the biosensor fabrication was kept constant in respect to the optimized amount in former studies since it was mainly focused on the experimental parameters that directly affect the PPO enzyme activity in apple tissue and the corresponding biosensor response [21, 28].

\subsubsection{Effect of working potential}

The effect of working potential was examined for the efficient monitoring of the enzyme catalyzed oxygen reduction. For this purpose, applied potential was varied as $-0.8 \mathrm{~V},-0.75 \mathrm{~V},-0.7 \mathrm{~V},-0.65 \mathrm{~V}$ and $-0.60 \mathrm{~V}$ and amperometric responses were measured for $200 \mu \mathrm{M}$ phenol (PB, pH 7.0). The highest response was obtained when $-0.7 \mathrm{~V}$ was applied as the working potential (Figure 1A) in accordance with a previous study [12]. Hence, $-0.7 \mathrm{~V}$ was applied throughout the study.

\subsection{2. pH effect}

Supporting electrolyte $\mathrm{pH}$ has a vital importance for maintaining suitable enzyme conformation leading to an effective enzyme-substrate interaction [11]. Therefore, $\mathrm{pH}$ effect on the amperometric response of $200 \mu \mathrm{M}$ phenol was studied in the range of $6.0-8.0$ with an 0.5 increment. As can be seen in Figure 1B, the maximum
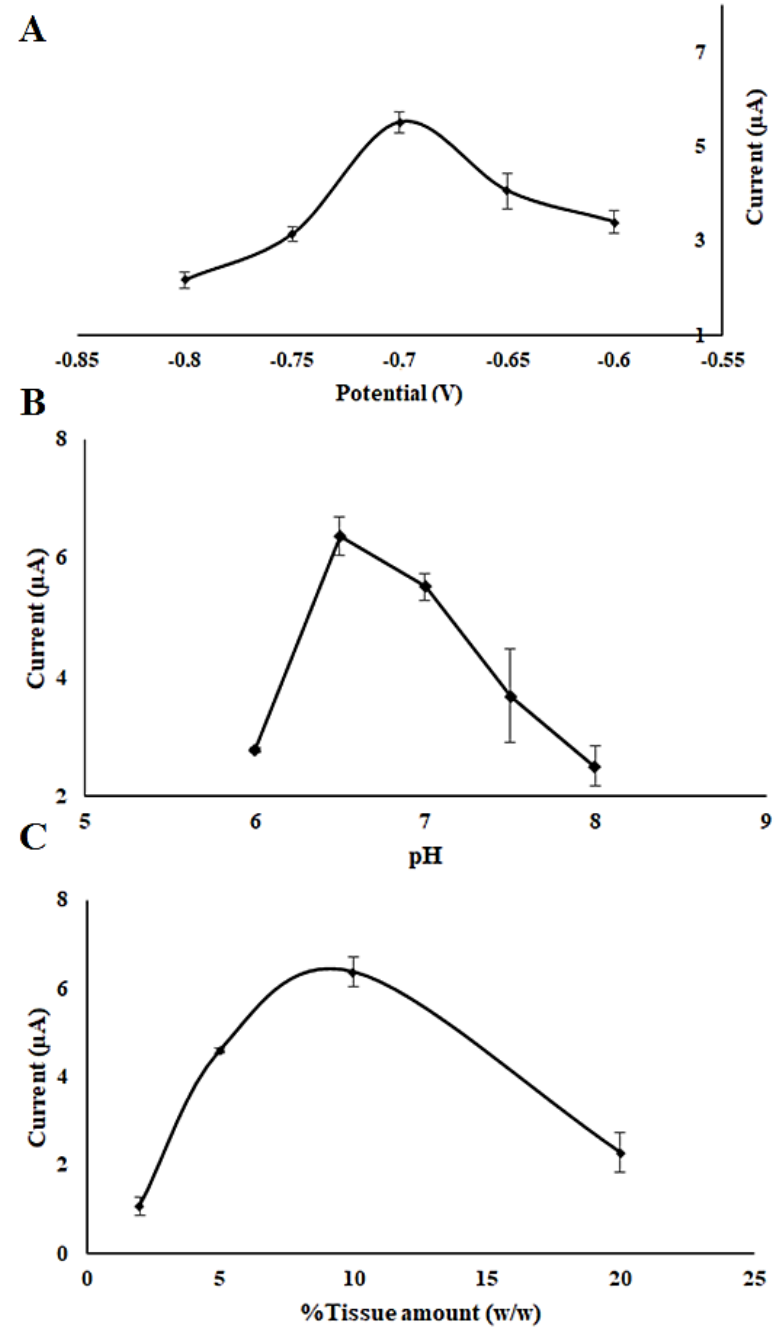

Figure 1. Effect of A. working potential, B. pH and C. $\%$ tissue amount (w/w) on $200 \mu \mathrm{M}$ phenol response. peak current was measured when $\mathrm{pH}$ was 6.5 . Thus, the following measurements were carried out at $\mathrm{pH} 6.5$.

\subsubsection{Effect of apple tissue amount}


The amount of apple tissue is directly related to the amount of PPO enzyme on the biosensor surface. Since this relation also closely interests the amperometric response, apple tissue amount was changed in biosensor composition as 2\%,5\%,10\% and 20\% by mass. As shown in Figure 1C, the biosensor composition with $10 \%$ apple tissue showed the maximum amperometric response for $200 \mu \mathrm{M}$ phenol.

\subsection{Analytical characteristics of apple tissue- fMWCNT-GCPE}

Amperometric responses of apple tissue-fMWCNT-GCPE were recorded by spiking increasing amounts of phenol to understand the analytical characteristics of the biosensor. As illustrated in Figure 2, a calibration plot was depicted serving a linear range between 10-200 $\mu \mathrm{M}$ under optimum conditions. The sensitivity of the biosensor can be estimated based on limit of detection (LOD) and limit of quantification (LOQ) and these values were calculated as $3.26 \mu \mathrm{M}$ and $10.87 \mu \mathrm{M}$, respectively

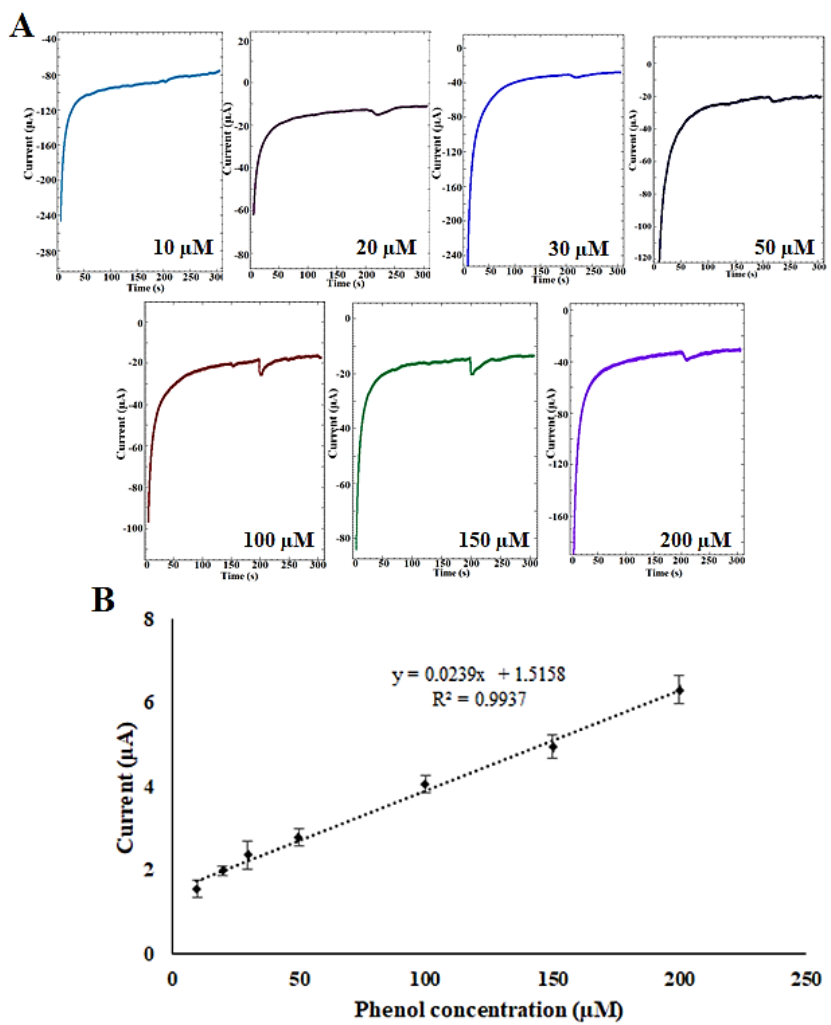

Figure 2. A. Chronoamperograms for 10-200 $\mu \mathrm{M}$ phenol (PB, pH 6.5) and B. the calibration plot.

$(n=3)$. The repeatability was tested in terms of relative standard deviation for $50 \mu \mathrm{M}$ and $200 \mu \mathrm{M}$ phenol and found to be $2.19 \%$ and $5.17 \%(n=3)$. The performance of apple tissue-fMWCNT-GCPE was compared with formerly reported electrochemical phenol biosensors in the literature as presented in Table 1. According to the data in Table 1, the fabricated biosensor exhibited comparable sensitivity and linearity.

Despite the fact that apple tissue-fMWCNT-GCPE was daily fabricated before measurements owing the advantage of practical preparation procedure, storage stability of the biosensor was also examined by monitoring the responses for $20 \mu \mathrm{M}$ phenol. For this purpose, apple tissue based biosensor was kept at $4^{\circ} \mathrm{C}$ for a week and at the end of the storage period, amperometric response of the biosensor was measured to be compared with its initial response. It was observed that apple tissue-fMWCNT-GCPE retained $97.2 \%$ of its initial activity.

\subsection{Interference study}

Amperometric response of biosensor to $100 \mu \mathrm{M}$ phenol was examined in the presence of $100 \mu \mathrm{M}$ uric acid, 100 $\mu \mathrm{M}$ ascorbic acid, $100 \mu \mathrm{M}$ cysteine and $100 \mu \mathrm{M}$ salicylic acid mixture in order to evaluate the selectivity of apple tissue based biosensor. Recovery value for $100 \mu \mathrm{M}$ phenol was calculated as 101.3 $\pm 3.6 \mu \mathrm{M}(n=3)$ indicating that apple tissue-fMWCNT-GCPE was not remarkably affected in the presence of equimolar interfering species.

Table 1. Comparison of apple tissue-fMWCNT-GCPE performance with the previously reported electrochemical biosensors for the phenol detection

\begin{tabular}{cccc}
\hline Biosensor & $\begin{array}{c}\text { Linear } \\
\text { range }\end{array}$ & LOD & Reference \\
\hline CPEB & $\begin{array}{c}\text { Not } \\
\text { presented }\end{array}$ & $\begin{array}{c}1.02 \\
\text { ppm } \\
(=10.84 \\
\mu \mathrm{M})\end{array}$ & {$[29]$} \\
& & $10 \mu \mathrm{M}$ & {$[1]$} \\
$\begin{array}{c}\text { ITO-silica-PVA- } \\
\text { tyrosinase fiber } \\
\text { mat }\end{array}$ & $10-250 \mu \mathrm{M}$ & & \\
$\begin{array}{c}\text { Tyr/MWCNT/SP } \\
\text { E }\end{array}$ & $2.5-75 \mu \mathrm{M}$ & $1.35 \mu \mathrm{M}$ & {$[30]$} \\
$\begin{array}{c}\text { HRP/ERG0/GCE } \\
\text { CV/NpAu/NTCP }\end{array}$ & $4.97-61 \mu \mathrm{M}$ & $4.81 \mu \mathrm{M}$ & {$[6]$} \\
$\begin{array}{c}\text { M-FtCo/Tir (Glu 2\%) } \\
\text { Apple tissue- }\end{array}$ & $10-200 \mu \mathrm{M}$ & $3.26 \mu \mathrm{M}$ & This work \\
fMWCNT-GCPE & & & \\
\hline
\end{tabular}

\subsection{Sample application}

Apple tissue based biosensor was tested for phenol detection in tap water samples. Initially, tap water samples were collected and buffered to the optimum $\mathrm{pH}$ (pH 6.5) according to a reported study [31]. $20 \mu \mathrm{M}$ phenol was spiked and recovery values were calculated to evaluate the utility of apple tissue based biosensor. Recovery was calculated as $103.39 \pm 2.36 \%(n=3)$ for 20 $\mu \mathrm{M}$ spiked phenol indicating the utility of the proposed biosensor in practical applications.

Maximum permissible phenol amounts in drinking water and wastewater samples are $0.1 \mathrm{ppm}(=1.06 \mu \mathrm{M})$ and 1 ppm $(=10.63 \mu \mathrm{M})$, respectively [32]. Thus, the developed biosensor can be used to accurately measure the phenol amount in wastewater samples rather than in drinking water samples. 


\section{Conclusion}

A practical and low-cost method for the preparation of apple tissue based biosensor was presented and applied for the phenol detection in this study. Obtained results confirmed that apple tissue-fMWCNT-GCPE provided a powerful tool in order to monitor phenolic compounds in tap water samples without the need of complicated sample pretreatment procedures. Furthermore, native enzymes in plant tissues have a potential for the fabrication of novel and unique biosensing platforms compared to commercially available enzymes, since the activity of enzyme is preserved in its own microenvironment. Even though PPO is able to catalyze the oxidation of a wide variety of phenolic compounds, the proposed biosensor can be used to detect the total phenolic contents of industrial wastewater samples. The utility of the proposed biosensor may be extended with the integration of multiple plant tissues that possess different enzymes for the simultaneous detection of various analytes in the single biosensor which may be an alternative to the dual enzymatic electrochemical biosensors as a future perspective.

\section{Acknowledgment}

The author would like to thank Prof. Ülkü Anık for the valuable mentorship and support throughout the study.

\section{References}

[1] Oriero, D.A., Gyan, I.O., Bolshaw, B.W., Cheng, I.F., Aston, D.E., "Electrospun biocatalytic hybrid silica-PVAtyrosinase fiber mats for electrochemical detection of phenols", Microchemical Journal, 118, 166-175, 2015.

[2] Ahmad, N.M., Abdullah, J., Yusof, N.A., Ab Rashid, A.H., Abd Rahman, S., Hasan, M., "Amperometric biosensor based on zirconium oxide/polyethylene glycol/tyrosinase composite film for the detection of phenolic compounds", Biosensors, 6, 31, 2016.

[3] Kaffash, A., Zare, H.R., Rostami, K., "Highly sensitive biosensing of phenol based on the adsorption of the phenol enzymatic oxidation product on the surface of an electrochemically reduced graphene oxide-modified electrode", Analytical Methods, 10, 2731-2739, 2018.

[4] Merkoçi, A., Anik, U., Çevik, S., Çubukçu, M., Guix, M., "Bismuth film combined with screen - printed electrode as biosensing platform for phenol detection", Electroanalysis, 22, 1429-1436, 2010.

[5] Ören, T., Tepeli, Y., Anik, Ü., "Bismuth Nanoparticles Incorporated Centri-voltammetry for Phenol Detection", Electroanalysis, 27, 2838-2844, 2015.

[6] de Oliveira, D.P., Ribeiro, F.W., Becker, H., Lima-Neto, P., Correia, A.N., "Biossensor eletroquímico baseado na enzima tirosinase para a determinação de fenol em efluentes", Química nova, 38, 924-931, 2015.

[7] Rahimi - Mohseni, M., Raoof, J.B., Aghajanzadeh, T.A., Ojani, R., "Rapid Determination of Phenolic Compounds in Water Samples: Development of a Paper - based Nanobiosensor Modified with Functionalized Silica Nanoparticles and Potato Tissue", Electroanalysis, 31, 2311-2318, 2019.

[8] Wang, Y., Zhai, F. Hasebe, Y., Jia, H., Zhang, Z., "A highly sensitive electrochemical biosensor for phenol derivatives using a graphene oxide-modified tyrosinase electrode", Bioelectrochemistry, 122, 174-182, 2018.

[9] Wen, Y., Li, R., Liu, J., Zhang, X., Wang, P., Zhang, X., Zhou, B., Li, H., Wang, J., Li, Z., "Promotion effect of Zn on 2D bimetallic NiZn metal organic framework nanosheets for tyrosinase immobilization and ultrasensitive detection of phenol", Analytica Chimica Acta, 1127, 131139, 2020.

[10] Sulak, M.T., Erhan, E., Keskinler, B., "Electrochemical phenol biosensor configurations based on nanobiocomposites", Sensors and Materials, 24, 141152, 2012.

[11] Arslan, H., Şenarslan, D., Çevrimli, B., Zengin, H., Uzun, D., Arslan, F., "Preparation of carbon paste electrode containing polyaniline-activated carbon composite for amperometric detection of phenol", Bulgarian Chemical Communications, 50, 16-20, 2018.

[12] Ozcan, H.M., Sagiroglu, A., "A novel amperometric biosensor based on banana peel (Musa cavendish) tissue homogenate for determination of phenolic compounds", Artificial Cells, Blood Substitutes, and Biotechnology, 38, 208-214, 2010.

[13] Singh, A.K., Verma, N., "4 Plants and plant-derived materials used for biosensor development", Industrial Biotechnology: Plant Systems, Resources and Products, 73, 2019.

[14] Raymundo-Pereira, P.A., Silva, T.A., Caetano, F.R., Riboviski, L., Zapp, E., Brondani, D., Bergamini, M.F., Junior, L.H.M., Banks, C.E., Oliveira Jr, O.N., Janegitz, B.C., Fatibello-Filho, O., "Polyphenol oxidase-based electrochemical biosensors: A review", Analytica Chimica Acta, 1139, 198-221, 2020.

[15] Zavar, M.H.A. Heydari, S., Rounaghi, G.H., "Electrochemical determination of salicylic acid at a new biosensor based on polypyrrole-banana tissue composite", Arabian Journal for Science and Engineering, 38, 29-36, 2013.

[16] Lupetti, K.O., Zanotto-Neto, G., Fatibello-Filho, O., "Sweet potato tissue-epoxy resin composite biosensor for hydroquinone determination in photographic process wastewater", Journal of the Brazilian Chemical Society, 17, 1329-1333, 2006.

[17] Narang, J., Chauhan, N., Singh, A., Pundir, C., "A nylon membrane based amperometric biosensor for polyphenol determination", Journal of Molecular Catalysis B: Enzymatic, 72, 276-281, 2011.

[18] Rodríguez, M.C., Rivas, G.A., “Glassy carbon paste electrodes modified with polyphenol oxidase: analytical applications", Analytica Chimica Acta, 459, 43-51, 2002.

[19] Burton, S.G., "Biocatalysis with polyphenol oxidase: a review", Catalysis Today, 22, 459-487, 1994.

[20] Gul, I., Ahmad, M.S., Naqvi, S.S., Hussain, A., Wali, R., Farooqi, A.A., Ahmed, I., "Polyphenol oxidase (PPO) based biosensors for detection of phenolic compounds: a review", Journal of Applied Biology\&Biotechnology, 5, 72-85, 2017.

[21] Çevik, S., Anik, Ü., "Banana tissue-nanoparticle /nanotube based glassy carbon paste electrode biosensors for catechol detection", Sensor Letters, 8, 667-671, 2010.

[22] Broli, N., Vallja, L., Shehu, A., Vasjari, M., "Determination of catechol in extract of tea using carbon 
paste electrode modified with banana tissue", Journal of Food Processing and Preservation, 43, e13838, 2019.

[23] Fatibello-Filho, O., Lupetti, K.O., Vieira, I.C., "Chronoamperometric determination of paracetamol using an avocado tissue (Persea americana) biosensor", Talanta, 55, 685-692, 2001.

[24] Varol, T.Ö., Anik, Ü., "Fabrication of multi-walled carbon nanotube-metallic nanoparticle hybrid nanostructure based electrochemical platforms for sensitive and practical colchicine detection", New Journal of Chemistry, 43, 13437-13446, 2019.

[25] Mehmood, S., Naeem, A., Sabahat, S., Ciancio, R., Carlino, E., Bhopal, M., Bhatti, A., "Modified structural and optical characteristics of Au-NPs-MWCNTs nanohybrids", Superlattices and Microstructures, 81, 248-264, 2015.

[26] Chen, Y., Tan, T., "Dopamine sensing and selectivity of Nafion-coated plant tissue powder sensors", Talanta, 42, 1181-1188, 1995.

[27] Cummings, E., Mailley, P., Linquette-Mailley, S., Eggins, B., McAdams, E., McFadden, S., "Amperometric carbon paste biosensor based on plant tissue for the determination of total flavanol content in beers", Analyst, 123, 1975-1980, 1998.

[28] Anik, Ü., Cubukcu, M., "Examination of the electroanalytic performance of carbon nanotube (CNT) modified carbon paste electrodes as xanthine biosensor transducers", Turkish Journal of Chemistry, 32, 711-719, 2008.

[29] Vasjari, M., Parroj, N., "Phenolic biosensor based on carbon paste electrode modified with crude tissue", University of Tirana, Department of Chemistry Faculty of Natural Sciences, 2012.

[30] Guix, M., Pérez-López, B., Sahin, M., Roldán, M., Ambrosi, A., Merkoçi, A., "Structural characterization by confocal laser scanning microscopy and electrochemical study of multi-walled carbon nanotube tyrosinase matrix for phenol detection", Analyst, 135, 1918-1925, 2010.

[31] Coroş, M., Pogăcean, F., Măgeruşan, L., Roşu, M.-C., Porav, A.S., Socaci, C., Bende, A., Stefan-van Staden, R.-I., Pruneanu, S., "Graphene-porphyrin composite synthesis through graphite exfoliation: The electrochemical sensing of catechol", Sensors and Actuators B: Chemical,, 256, 665-673, 2018.

[32] Eletta, O.A.A., Tijani, I.O., Ighalo, J.O. "Adsorption of $\mathrm{Pb}(\mathrm{II})$ and phenol from wastewater using silver nitrate modified activated carbon from groundnut (Arachis hypogaea L.) shells", The West Indian Journal of Engineering, 43, 26-35, 2020. 